\title{
Banking Market Structure and Cost of Credit in the WAEMU
}

\author{
PRAO Yao Séraphin ${ }^{1}, \&$ Bakayoko Mamadou ${ }^{1}$ \\ ${ }^{1}$ Laboratory of of Economic Policies' Analysis and Modeling, Alassane Ouattara University, Bouaké, Ivory Coast \\ Correspondence: PRAO Yao Séraphin, Laboratory of of Economic Policies' Analysis and Modeling, Alassane \\ Ouattara University, Bouaké, 01 BP V18 BOUAKE 01, Ivory Coast.
}

Received: June 15, 2020

doi:10.5539/ibr.v13n8p78

\author{
Accepted: July 2, 2020 \\ Online Published: July 21, 2020 \\ URL: https://doi.org/10.5539/ibr.v13n8p78
}

\begin{abstract}
This paper provides an empirical assessment of the relationship between the structure of the banking market and the cost of credit in the WAEMU. The analysis focuses on WAEMU countries except for Guinea-Bissau due to the lack of sufficiently long series. The study covers the period from 1996 to 2017. Using the fully modified ordinary least squares (FMOLS) method, we show that the banking market concentration ratio has a double effect on the cost of credit. First, the concentration ratio increases the cost of credit, and second, it decreases the cost of credit after reaching a threshold of 70 percent. Moreover, the results highlight the positive impact of the money market interest rate on the cost of credit. On the other hand, the inflation rate unexpectedly lowers the cost of credit in the WAEMU.
\end{abstract}

Keywords: market structure, bank concentration, cost of credit, DOLS, WAEMU

\section{Introduction}

Financing is an important pillar of any economic activity. In the absence of adequate financing, the investment needs of companies are not covered. Also, the creation of new businesses is stagnating, established businesses are struggling to develop an economic growth is slowing down. The role of finance in economic development has long divided economists. For Robinson (1952), "where business leads, finance follows" and for Lucas (1988), finance is an overestimated determinant of economic growth. Since growth is only the product of the real sector, finance only responds to real phenomena and, in this sense, would have no impact in itself on economic development. However, other economists recognize the impact of finance on economic growth as early as the end of the 19th century with Bagehot (1873) or at the beginning of the 20th century with Schumpeter (1912). For the latter, the banking system plays a central role in economic growth, by allocating savings to productive projects. For Levine (2005), more recent research on the link between growth and finance suggests that «(1) countries with better-functioning banks and markets develop more rapidly; (2) the simultaneity bias does not seem to affect these conclusions; and (3) increased efficiency of financial systems reduces constraints on the external financing of firms, indicating that this is one of the mechanisms by which the development of financial markets influences growth ». King and Levine (1993) argue that financial development has a positive impact on economic growth through a variety of channels, including reducing the cost of external financing to firms and increasing the efficiency of resource allocation. Based on this work, subsequent studies have shown that the plurality of banking institutions in a financial system is a much more important factor. According to Simpasa (2013), effective competition in the banking sector can reduce the cost of financial intermediation, improve the provision of high-quality services and, in turn, improve consumer welfare. Besides, Claessens and Laeven (2003) and Anginer et al. (2014) indicate that banking competition generally reduces the costs of financial intermediation and improves firms' access to external financing. Competition can be seen as an incentive to reduce the costs of banking services or products, and to innovate, especially to improve technological infrastructure (Nickell, 1996). Banking competition is therefore desirable for borrowers. But concentration in the banking market also has positive effects, at least from a theoretical point of view. Indeed, in the absence of competition, large and well-established banks in the banking market can offer lower interest rates to their customer's thanks to economies of scale, thus attracting young companies. In this sense, Diagne (2011) finds that access to finance for small firms has remained very low despite the entry of several new banks into the banking market in Senegal. Similar results were observed in the United States by Petersen and Rajan (1995) who concluded that increased competition in the local credit market is negatively associated with access to small business finance. Overall, this brief review shows that the structure of the market influences the cost of bank 
credit.

In the WAEMU zone, the number of banks has changed considerably in recent years, rising from 55 in 1995 to 126 in 2017 (WAEMU Banking Commission Report, 2018). The state of the banking market structure, as measured by the banking concentration ratio (CR3), fell from $80 \%$ to $75 \%$ between 2000 and 2006, a reduction of 5 percentage points. Over the same period, the cost of bank lending declined from $12.8 \%$ to $11.4 \%$. Based on these two developments, it could be assumed that competition between banks in the area is reducing the cost of bank lending. In contrast, between 2010 and 2016 competition among banks continued to intensify, with the bank concentration ratio declining by 20 percentage points to $58 \%$, while the cost of credit increased from $9.6 \%$ to $10.02 \%$. Of the latter two relationships, banking competition appears to increase the cost of credit. Given these various developments, the relationship between the cost of credit and the structure of the banking market appears ambiguous. Thus, the central issue of this study revolves around the following fundamental question: to what extent does the structure of the banking market influence the cost of credit in the WAEMU zone?

Thus, the main objective of this study is to empirically analyze the effect of the structure of the banking market on the cost of credit in the WAEMU. Specifically, it is:

- (i) analyze the impact of banking market concentration on the cost of credit in the WAEMU;

- (ii) to examine the influence of the increase in the money market interest rate on the cost of credit in the WAEMU.

To achieve these objectives, we assume the following two hypotheses. First, there is a threshold beyond which bank market concentration increases the cost of bank credit. Second, an increase in the money market interest rate increases the cost of bank credit.

There is no lack of interest in this study. Indeed, very few studies have focused on the link between the structure of the banking market and the cost of credit in the WAEMU. This study, therefore, makes an empirical contribution to this subject in the WAEMU zone. Moreover, the banking structure is of particular interest to the BCEAO in terms of the transmission of key rates to the interest rates applied by banks. The results of this study could, therefore, help the monetary authorities of the union to put in place adequate financial reforms.

Methodologically, the study is based on the FMOLS estimator developed by Pedroni (1996) and Philips and Moon (1999). The Fully Modified Least Squares Method (FMOLS) is based on a non-parametric approach that takes into account the effect of serial correlation while solving the problem of regressor endogeneity. Also, this method produces reliable estimates on small samples and provides robust results. The study uses annual data covering the period 1996 to 2017 and the choice of this period is dictated by data availability. Our data are drawn primarily from three major sources: the Central Bank of West African States (BCEAO, 2019), the World Bank's Global Financial Development Data (GFDD, 2018), and the World Development Indicator (WDI, 2018).

This article is organized as follows: Section 2 is devoted to a review of the literature on the relationship between the structure of the banking market and the cost of credit. Section 3 presents the methodology of the study. Section 4 presents the data source and the description of the variables. Section 5 will discuss the empirical results, particularly the econometric analysis of the relationship between the structure of the banking market and the cost of credit. Section 6 is reserved for the conclusion of the study.

\section{Literature Review}

This section reviews the theoretical and empirical literature on the link between the structure of the banking market and the cost of credit. For the sake of clarity, we first present a review of the theoretical literature and second, a review of the empirical literature.

\subsection{Review of Theoretical Literature}

At the theoretical level, the theoretical basis of the relationship between the structure of the banking market and the cost of credit lines in the opposition between the Structure-Behavior-Performance (SCP) and the Structure-Efficiency (ES) hypothesis. Concerning the Structure-Behaviour-Performance (SCP) hypothesis, formulated by Bain (1959), the fundamental idea of SCP is based on the fact that banking behavior is determined by the structure of the market, whose key factors are the number, size, and concentration of suppliers (Dietsch, 1992). Depending on the structure, the quantities offered, prices, and bank profits are immediately determined. Thus, from the SCP perspective, bank concentration tends to bring the market closer to an oligopoly equilibrium, or even a monopoly. The pricing of banking products in a situation of concentration in the sector is then characterized, in contrast to a situation of perfect competition, by higher lending rates and lower deposit rates. Thus, in imperfectly competitive markets, prices are less favorable to consumers, with high lending rates and 
relatively low deposit rates (Bourke, 1989). From this perspective, Hannan (1991) shows that the more concentrated the market, the higher the banks' profits. Thus, a concentrated market provides banks with higher profits. In such a market, banks can merge and take advantage of higher interest rate margins. This merger behavior increases as market share become concentrated in the hands of a few companies (Samad, 2008). Thus, firms in a concentrated market will make higher profits than those operating in a less concentrated market, regardless of their efficiency. Furthermore, it is interesting to note that a concentrated market contributes to the reduction of information asymmetries. Indeed, in non-competitive markets, banks build long-term relationships with their customers, which helps them to better know the profile of each customer, and ultimately reduces the risk of default. Marquez (2002) argues that borrower-specific information becomes more dispersed in competitive banking markets, leading to a less efficient selection of borrowers, and most likely higher interest rates. However, banking competition could improve the stability of the banking sector by mitigating the risks taken by banks (Acharya et al 2016) and by reducing systemic risk in the banking sector (Anginer et al 2014). A priori, a competitive market structure should encourage banks to reduce their bank margins in order to increase market share, or at least to preserve their customer base. The SCP model has yielded important results on the understanding of bank behavior. However, this approach has its limitations. First, it focuses on market power to explain the behavior of the banking firm. However, changes in interest rates also depend on the conditions of competition in the sector (Klein, 1971). Second, in concentrated markets, banks are likely to be less efficient in collecting deposits, offer less credit and, all other things being equal, be more profitable. As a result, greater concentration is not necessarily beneficial and may even be an impediment to business financing. This is one of the reasons for adopting another approach known as the Efficient Structure (ES) hypothesis. Founded by Demsetz (1973), the Efficient Structure Hypothesis (ES) states that the increase in profits is not due to collusion but rather to the efficiency of firms in the market. Indeed, cost efficiencies achieved through economies of scale and scope allow banks to increase their market share. For example, firms with management technologies, higher production capacity, or economies of scale have lower operating costs and higher profits. To illustrate this idea, Berger and Hannan (1989) find that the most efficient firms produce and price closer to marginal cost. From this finding, it appears that market concentration is the result of bank efficiency. From a general perspective, efficient structure theory is based on two main axes: X-efficiency and scale efficiency. The first argues that market concentration results from the efficiency of the firm. Indeed, companies with superior management technologies or production have lower costs and therefore higher profits. As a result, the increase in market power and profitability of banks is attributable to operational efficiency and not to collusive behavior as indicated by the SCP paradigm (Athanasoglou et al. 2006). The second efficiency of scale hypothesis indicates that the effectiveness of banks depends on their ability to achieve economies of scale, allowing them to reduce costs and achieve higher profits (Thoraneenitiyan 2010). As a result, efficient and competitive banks grow to become larger to achieve greater market share and also greater profits. These theoretical links have been the subject of empirical studies.

\subsection{Review of Empirical Literature}

To achieve coherence in the presentation of the studies, we start first with those that focus on developed countries, then on emerging countries and finally on African countries. Concerning developed countries, De Young and Noll (1996) conducted a study on a small sample of small and large banks present on the American banking market. The results of the study indicate that bank concentration positively influences lending to small firms in urban areas but negatively influences lending to those in rural areas. Moreover, the authors find that the pricing of banking products in a concentrated banking environment is characterized by higher lending rates and lower lending rates compared with a perfectly competitive environment. Based on a sample of 53 developing countries, Love and Peria (2012) analyzed the effect of bank concentration on access to corporate finance. The results of the study show that firms have very little access to bank finance in a highly competitive banking environment, giving support for the market power view. Ryan et al (2014) examined the effect of the market power of banks on SME credit constraints, using panel data from more than 118,000 SMEs in 20 European countries over the period 2005-2008. The results support the market power hypothesis that increases in market power lead to increased financing constraints for SMEs. Furthermore, they find that the effect of bank market power on financing constraints increases in bank-dominated financial systems. For their part, Ryan et al. (2014) examine the effect of bank market power on SME credit constraints, using panel data from more than 118,000 SMEs in 20 European countries over the period 2005-2008. The results show that banking market power can have negative effects, as it increases the financing constraints on small and medium-sized enterprises. Furthermore, they find that the effect of bank market power on financing constraints increases in financial systems that are more dependent on banks. Using a panel of firms from 20 European countries, covering the period 2001-2011, Fungáčová et al. (2017) find that bank competition increases the cost of credit, especially for 
small firms. Such results indicate that in a situation of bank concentration, banks are willing to invest in information, which helps them to know borrowers better and thus lower the cost of credit. In contrast, Canta et al (2018) studied the relationship between competition and risk-taking in banking markets in Norway. The results indicate that increased competition leads to greater risk exposure. Moreover, by examining the effects of banking competition on the availability of loans, they concluded that increased competition leads to lower interest rates and higher loan volumes for small and newly established businesses. Concerning emerging countries, some studies exist. Using a survey on the financing of small and medium-sized enterprises in China, combined with detailed bank branch information, Chong et al (2013) investigate how concentration in the local banking market affects the availability of credit. They find that lower market concentration alleviates financing constraints. Turk-Ariss (2010) examines the effect of market power on the efficiency and stability of banks in developing economies. The results indicate that an increase in market power leads to greater banking stability and improved profitability. Such results confirm the traditional view that increased competition can undermine the stability of banks and can have important implications for banking systems in developing economies. As a result, efficiency could be one channel through which the effects of market power can be diffused. Indeed, Schaeck and Cihák (2014) reach these conclusions. Concerning the studies conducted in Africa, it is possible to list only a few. Ephraim and Montfort (2004) examine the effect of financial sector reforms on bank interest rate spreads in Malawi. They find that interest rate spreads increased significantly after liberalization and that the observed spreads can be attributed to high lending rates, monopoly power, high reserve requirements, high policy rates, and high inflation.

For Ghana, Adoah (2015) studies the determinants of bank lending rates. The author finds that the policy rate, the treasury bill rate, inflation, GDP, bank size, and the HHI concentration index are the main determinants of lending rates in Ghana. In Kenya, Itimu and Abdul (2018) examines the determinants of average commercial bank lending rates, based on a sample of 11 publicly traded commercial banks. The results indicate that specific factors such as capital adequacy, liquidity risk, bank size, non-performing loans determine the average lending rates of commercial banks in Kenya. For WAEMU countries, over the period from 1991 to 2009, Ouédraogo (2012) analyzed the relationship between bank competition and profitability. Using four different measures of bank concentration, the number of banks, the CR3 and CR2 ratios, and the HHI index, he was able to establish that concentration positively affects financial profitability (ROE) and bank economic performance (ROA) but limits the development of the banking sector.

\section{Empirical Strategy}

In this section, we present, first, the model specification and, second, the estimation method.

\subsection{Model Specification}

Our model is based on that of Fungacovà et al (2017) with some modifications. Thus, the model to be estimated in this study is specified as follows:

$$
\begin{gathered}
C C_{i t}=\alpha_{0}+\alpha_{1} C R 3_{i t}+\alpha_{2} C R 3_{i t}^{2}+\alpha_{3} C R E D I T_{i t}+\alpha_{4} G D P_{i t}+\alpha_{5} T M M_{i t}+\alpha_{6} I N F_{i t}+ \\
\alpha_{7} S T P_{i t}+\varepsilon_{i t}
\end{gathered}
$$

Where CC represents the cost of bank credit granted to economic agents. The cost of bank credit, commonly referred to as the lending rate, is obtained by a functional aggregation, expressed as an annual average, of the individual rates charged by banks. CR3 is the bank concentration ratio and $\mathrm{CR} 3^{2}$ is the banking concentration ratio squared to capture a threshold effect. The CR3 concentration ratio is defined as the aggregate assets of the three largest commercial banks as a percentage of total commercial bank assets. When the banking market in a country or area is highly concentrated, this means that a small number of banks can change the market environment to the detriment of other banks. CREDIT represents bank credit to the economy. Also, GDP represents the ratio of gross domestic product to the total population. It is an indicator of a country's level of wealth. An increase in GDP per capita increases the ability of borrowers to meet their commitments. MMR is the money market interest rate. Also called the interbank market rate, it is the rate at which commercial banks borrow and lend short-term money to each other. INF is the rate of inflation, which is measured here by the growth rate of the consumer price index (CPI). STP is the political stability index. It is an assessment of the government's ability to carry out its stated program and its ability to stay in power. It varies between -2.5 and +2.5. A score closer to -2.5 corresponds to more political instability in the country, a score closer to +2.5 corresponds to less political instability. Lower political instability reduces market uncertainty. Finally, $\alpha_{i t}$ represents the coefficients of the explanatory variables to be estimated; $\varepsilon_{i t}$ the error term; i the country index and $t$ the time index. 


\subsection{Method of Estimation}

In the following lines, we first present the preliminary econometric tests and the estimation technique.

\subsubsection{Preliminary Economic Tests}

Before using any time series to perform econometric regressions, it is essential to test the stationarity of the variables. Note that a time series is said to be stationary when its statistical properties do not vary over time. To test the stationarity of these series, it is possible to use two tests, namely the Augmented Dickey-Fuller (ADF) test, and the Phillips-Perron test. The first is more efficient in the presence of autocorrelation of errors and the second is recommended in the presence of heteroskedastic errors (Kuma, 2018). Several tests allow testing the stationarity of variables with panel data. In our study, we use the second generation unit root tests of Pesaran (2007) and Breitung de Das (2005) because of the interdependence between the individuals in our study. After the unit root test, if it turns out that the studied series are non-stationary, then the cointegration tests can be performed. Two series are said to be cointegrated if one or more long-term equilibrium relationships exist between them. To verify whether the series studied are cointegrated, the econometric literature provides several tests or approaches, including the Engel and Granger (1987), Johansen (1988), Johansen and Juselius (1990) and Pesaran al. (2001) tests. The first two help to verify cointegration only between similar integrated series, which is not always the case in practice. They are not suitable for cases where series are not integrated into the same order and where there are more than two variables. Johansen's (1988) and Johansen's (1991) paper was designed to test cointegration on more than two variables. However, it is also limited insofar as it is not suitable for situations where series are integrated in a different order $(\mathrm{I}(0)$, I(1)). It is also important to check the non-dependence between individuals in the panel. We then test the hypothesis of non-dependence between individuals using the Breusch-Pagan test. As a result, given the possible interdependence between individuals in the panel, we opt for the Pedroni (1999) test, which solves this problem.

\subsubsection{The Estimation Technique}

The choice of the estimation technique depends on the conditions of the econometric tests presented above. Thus, if the conditions of the unit-root and cointegration tests are met, then it will be possible to use the Fully Modified (FM) method initially proposed by Phillips and Hansen (1990), then extended by Phillips (1995), which is a semi-parametric procedure for estimating the parameters of a cointegrating relationship that corrects for the long-run endogeneity bias. Indeed, the use of the Ordinary Least Square Method (OLS) results in biased estimates in the estimation of long-run equations on panel data (Pedroni, 2001). To overcome this problem, Pedroni (2001) proposes the Fully Modified Ordinary Least Square Estimator (FMOLS). The distribution of the estimators obtained by this method is independent of the nuisance parameters present in the OLS distribution. Therefore, the statistics of the usual tests applied to modified least squares estimators follow standard distributions identical to those used in a stationary universe. The main advantage of this method lies in its ease of implementation. Modified least squares simply involve applying OLS to a transformed model. The transformation used is obtained from a convergent estimator of the long-run variance-covariance matrix of the residuals and the innovations of the non-stationary variables. The intuition of the chosen transformation is very simple. The goal is to orthogonalize the residual of the cointegrating relationship concerning the innovations of the non-stationary variables. Once the system has been rewritten so that the residual of the cointegrating relation is orthogonal to the innovations of the I (1) regressors, then OLS can be applied.

The distribution of the estimators is in this case independent of the nuisance parameters, centered and symmetrical. In our study, we use the FMOLS method because it produces reliable estimates on small sample sizes and allows us to verify the robustness of the results. However, since we are working on panel data, it is necessary to ensure the homogeneous or heterogeneous specification of the data generating process. This amounts to testing the equality of the coefficients of the model studied in the individual dimension. From an economic point of view, the specification test makes it possible to determine whether the theoretical model is perfectly identical for all countries or whether there are country-specificities. There are several specification tests. In this study, we use Fisher's test, which consists of choosing between a homogeneous model and a specific effects model. It is a test that makes it possible to justify whether it is appropriate to estimate the model on panel data or whether it is more appropriate to estimate the model on a country-by-country basis. The principle of the test is as follows: $H_{0}$ : the homogeneous model versus $H_{1}:$ the individual effect model. 


\section{Data and Descriptive Evidence}

In this section, we present the data source and descriptive statistics for the variables in the model.

\subsection{Data}

The empirical study is based on a panel of 7 WAEMU countries over the period 1996-2017. The data used for the estimates come essentially from three major sources: the Central Bank of West African States (BCEAO, 2019), the World Bank's Global Financial Development Data (GFDD, 2018), and the World Development Indicator (WDI, 2018). Table 1 below provides information on the variables used, the expected effects, and the sources of the data.

Table 1. Variables and Expected Effects

\begin{tabular}{lll}
\hline EXOGENOUS VARIABLES & ABBREVIATION & EXPECTED SIGN \\
\hline \multicolumn{1}{c}{ Banking market concentration ratio } & CR3 & - \\
\hline Banking market concentration ratio squared & CR3 & + \\
\hline Credit to the economy & CREDIT & - \\
GDP per capita & GDP & - \\
\hline Inflation rate & INF & + \\
\hline Money market rates & TMM & + \\
\hline Political Stability & STP & - \\
\hline
\end{tabular}

Source: Author, based on economic literature.

To describe our variables properly, we adopt a dependent and independent variable categorization. The endogenous variable is the cost of credit (CC), which here represents the lending rate obtained by functionally aggregating, expressed as an annual average, the individual rates charged by banks. For De Bock and Demyanets (2012), it is the price that a borrower pays for the use of the money he borrows from a lender/financial institution or fees paid on borrowed assets. The lending rate charged by banks differs from one economic agent to another depending on the creditworthiness or degree of risk incurred by the borrower.

Regarding the explanatory variables, let us start with the interest variable, the bank concentration ratio (CR3), defined as the total assets of the three largest commercial banks as a percentage of the total assets of commercial banks. When the banking market in a country or area is highly concentrated, it means that a small number of banks can change the market environment to the detriment of other banks. In theory, market concentration reduces competition between institutions, thereby facilitating cartels and anti-competitive practices. Thus, the expected sign for this variable and its square are negative and positive, respectively.

Regarding the control variables, we select five for their potential explanatory power of our dependent variable. First, we have credit granted to the economy, measured by the volume of total credit granted to the economy as a ratio of GDP. This ratio underlines the importance of the role played by the financial sector, in particular the deposit banks, in financing the economy. Thus, the expected sign for this variable is negative. Next, GDP per capita (GDP), which is an indicator of the level of economic activity in a country. An increase in GDP per capita enables borrowers to better honor their commitments. Therefore, the expected sign for this variable is negative. We also have the inflation rate, which refers to the generalized and continuous increase in prices and is generally expressed as an annual percentage change in the consumer price index. It contributes to currency depreciation.

Inflation affects banks because they generally trade in nominal financial instruments that make up the bulk of banks' assets and liabilities. The expected sign for this variable is positive. The money market rate, also known as the interbank market rate, is defined as the rate at which commercial banks lend each other central bank money or foreign exchange in the short term. It plays an important role in economic activity and fluctuates in response to inflation, unemployment, or international conjecture. An increase in the cost of refinancing, and thus in the money market rate, can have a positive impact on the cost of bank credit. The sign expected here is positive. Finally, the political stability index reflects a country's political situation. It is an assessment of the government's ability to carry out its stated programm and its ability to remain in power. It varies between -2.5 and +2.5 . A score closer to -2.5 corresponds to more political instability in the country, a score closer to +2.5 corresponds to less political instability. Lower political instability reduces uncertainty. The expected sign for this variable is therefore negative.

\subsection{Descriptive Statistics}

The descriptive analysis consists of making a synthetic and explicit description of the observed data in order to 
better analyze them. Thus, for this work, the variables will be studied in terms of their mean, standard deviation, minimum, and maximum. The descriptive statistics of the data are recorded in Table 2 below. The examination of this table provides information on the cost of credit in the WAEMU zone. The average cost of bank credit over the period 1996-2017 is 11.70 percent. At the same time, the bank concentration ratio stands at 76.15 percent, highlighting a highly concentrated banking sector in the zone. Moreover, the average GDP per capita is USD 723.13, with a standard deviation of 310.599. The high value of the standard deviation of income shows that the increase in income in the WAEMU over the period 1996-2017 did not benefit all social classes. The low inflation rate ( 2.26 percent) is explained by the price stability policy constantly pursued by the BCEAO. In addition, the average money market rate is 4.08 percent. Finally, the political stability index has an average of -0.37 percent, which means that WAEMU countries regularly face socio-political crises.

Table 2. Descriptive Statistics of Variables

\begin{tabular}{llllll}
\hline Variables & Observations & Moyenne & Ecart-type & Min & Max \\
\hline CC & 154 & 11.694 & 2.627 & 2.532 & 18.779 \\
CR3 & 154 & 76.146 & 15.719 & 40.015 & 100.000 \\
TMM & 154 & 4.083 & 0.928 & 2.510 & 5.34 \\
GDP & 154 & 723.133 & 310.599 & 322.149 & 1632.677 \\
INF & 154 & 2.281 & 2.607 & -3.099 & 11.305 \\
STP & 154 & -0.377 & 0.703 & -2.264 & 1.049 \\
\hline
\end{tabular}

Source: Author, based on data from GFDD (2018), WDI (2018) and BCEAO (2019).

Descriptive statistics will be complete if the correlations between the variables are studied to avoid the risk of multicollinearity. The results reported in Table 2 indicate that the cost of credit is positively related to bank concentration. In Table 3, the correlation coefficients between the explained variable and the explanatory variables are almost all significant at the 5 percent level. In addition, the correlations between the explanatory variables are moderate and low. Of all the explanatory variables, the pair of bank concentration ratio (CR3) and money market rate (TMM) has the highest correlation coefficient (0.365), but well below 0.8. Therefore, the impact of multicollinearity is not significant and all the explanatory variables in the model can be retained for analysis.

Table 3. Correlation Matrix between Pearson Variables

\begin{tabular}{l|llllll}
\hline & CC & cR3 & TMM & GDP & INF & stp \\
\hline CC & 1.000 & & & & & \\
Cr3 & $0.235^{*}$ & 1.000 & & & & \\
TMM & $0.622^{*}$ & $0.365^{*}$ & 1.000 & & & \\
GDP & $-0.154^{*}$ & $-0.182^{*}$ & $-0.135^{*}$ & 1.000 & & \\
INF & $-0.009^{*}$ & $0.241^{*}$ & $0.234^{*}$ & $0.092^{*}$ & 1.000 & \\
Stp & 0.123 & $0.283^{*}$ & $0.298^{*}$ & $0.136^{*}$ & 0.075 & 1.000 \\
\hline
\end{tabular}

Note: * refers to the significance of the parameters at the 5\% threshold

Source: Author, based on data from GFDD (2018), WDI (2018) and BCEAO (2019).

After these various descriptive statistics, we can now present the results of our estimates.

\section{Empirical Results}

The empirical analysis takes the following approach. First, we present the results of the homogeneity and dependence tests. Second, we present the results of the stationarity of the variables. Thirdly, we present the long-term coefficients from the estimates.

\subsection{Homogeneity and Dependency Test}

The test results are presented in Table 4 . The p-value associated with the test statistic is less than $1 \%$, so the null hypothesis of no specific effects at the $1 \%$ threshold is rejected. After the homogeneity test, we performed the dependency test. 
Table 4. Homogeneity Test Results

$\mathrm{F}(6.147)=\quad 19.12$
Prob $>\mathrm{F}=0.000$

Source: Author, based on data from GFDD (2018), WDI (2018) and BCEAO (2019).

The hypothesis of non-dependence between individuals is tested using the Breusch-Pagan test. The results of the test are presented in Table 5.

Table 5. Dependency test results

\begin{tabular}{lll}
\hline Variable & T-statistic & P-value \\
\hline Res & 20.70 & 0.000 \\
\hline
\end{tabular}

Source: Author, based on data from GFDD (2018), WDI (2018) and BCEAO (2019).

The p-value associated with the test statistic is less than $1 \%$, then the null hypothesis of independence is rejected. This indicates that the individuals in the study are dependent on each other. The second generation tests used will be those of Breitung and Das (2005) and Pesaran (2007).

\subsection{Unit Root and Cointegration Test Results}

One of the first steps in the time series modeling approach is to check the stationarity of the data generating process. This is because most analyses are done on a long series. These series are subject to perturbations of various origins that tend to modify the variance of the data, which sometimes biases the estimation results. In this study, the order of integration of the variables is tested following the second-generation tests of Pesaran (2007) and Breitung and Das (2005). The choice of the second generation tests is because, unlike the first generation test, they take into account the interdependence between individuals in the panel. The results of the test summarised in Table 6 show that at the 5\% threshold, the null hypothesis confirming the presence of unit root cannot be rejected for all level variables. The variables are all stationary after taking the first difference. Thus, there is a presumption of a cointegrating relationship between the different variables.

Table 6. Stationarity Test Results

\begin{tabular}{|c|c|c|c|c|c|}
\hline \multirow[b]{2}{*}{ Variables } & \multirow{2}{*}{$\begin{array}{l}\text { At Level } \\
\text { Pesaran }\end{array}$} & \multicolumn{3}{|c|}{ In First Difference } & \multirow[b]{2}{*}{ Decision } \\
\hline & & Breitung \& Das & Pesaran & Breitung \& Das & \\
\hline $\mathrm{CC}$ & $\begin{array}{l}-4.029 * * \\
(0.000)\end{array}$ & $\begin{array}{l}-2.285^{*} \\
(0.011)\end{array}$ & - & - & $\mathrm{I}(0)$ \\
\hline CR3 & $\begin{array}{c}-0.669 \\
(0.251)\end{array}$ & $\begin{array}{l}-3.069 * * \\
(0.001)\end{array}$ & $\begin{array}{l}-8.675^{* *} \\
(0.000)\end{array}$ & $\begin{array}{l}-4.425^{* *} \\
(0.000)\end{array}$ & I (1) \\
\hline $\mathrm{CR}^{2}$ & $\begin{array}{c}-1.888^{*} \\
(0.030)\end{array}$ & $\begin{array}{l}-3.117 * * \\
(0.000)\end{array}$ & - & - & $\mathrm{I}(0)$ \\
\hline TMM & $\begin{array}{l}-0.327 \\
(0.371)\end{array}$ & $\begin{array}{l}1.742 \\
(0.959)\end{array}$ & $\begin{array}{l}-3.272 * * \\
(0.000)\end{array}$ & $\begin{array}{l}-3.669 * * \\
(0.000)\end{array}$ & I (1) \\
\hline GDP & $\begin{array}{l}4.885 \\
(1.000)\end{array}$ & $\begin{array}{l}2.111 \\
(0.982)\end{array}$ & $\begin{array}{l}-5.414^{*} \\
(0.000)\end{array}$ & $\begin{array}{l}-5.261 * * \\
(0.000)\end{array}$ & $\mathrm{I}(1)$ \\
\hline INF & $\begin{array}{l}-6.147 * * \\
(0.000)\end{array}$ & $\begin{array}{l}-7.486^{* * *} \\
(0.000)\end{array}$ & - & - & $\mathrm{I}(0)$ \\
\hline STP & $\begin{array}{l}-2.076^{*} \\
(0.019)\end{array}$ & $\begin{array}{l}-1.172 \\
(0.120)\end{array}$ & $\begin{array}{l}-2.686^{* * *} \\
(0.003)\end{array}$ & $\begin{array}{l}-7.366^{* *} \\
(0.000)\end{array}$ & I (1) \\
\hline
\end{tabular}

Note: The values in brackets are the p-values $*(* *)$ means that the series is stationary at the threshold of $5 \%$ $(1 \%)$.

Source: Author, based on data from GFDD (2018), WDI (2018) and BCEAO (2019).

Table 7 presents the results of Pedroni's (1999) cointegration test. The choice of Pedroni's (1999) test is because, unlike Kao's (1999) cointegration test, it takes into account the interdependence between individuals in the panel. It appears that all three statistics in the test are in favour of the existence of a long-term relationship between the variables. We can therefore conclude that the variables are cointegrated and an error-correction model will be used to estimate the long-term relationship. 
Table 7. Result of Pedroni's (1999) Cointegration Test

\begin{tabular}{lll}
\hline & T-statistique & P-value \\
\hline Phillips-Perron Modifié t & $3.134^{* *}$ & 0.000 \\
Phillips-Perron t & $-2.964 * *$ & 0.001 \\
Dickey-Fuller Augmenté t & $-3.404^{* *}$ & 0.000 \\
\hline
\end{tabular}

Note : The asterisk $* *$ indicates significance at the $1 \%$ levels.

Source: Author, based on data from GFDD (2018), WDI (2018) and BCEAO (2019).

At present, we can present and interpret the econometric and economic results of the long-term parameters by the FMOLS method.

\subsection{Results of Parameter Estimation by the FMOLS Method}

The results are recorded in Table 8 below. The estimation results show that all the coefficients of the variables are significant at the 5\% threshold except for the CREDIT variable which is significant at the $10 \%$ threshold. Also, it is noted that the bank concentration ratio (CR3) and the money market rate (MMR) positively affect the cost of bank lending, while the concentration squared ratio $\left(\mathrm{CR} 3^{2}\right)$, the credit supply (CREDIT) and the inflation rate (INF) negatively affect the cost of credit.

In terms of interpreting the results, we find that bank concentration increases the cost of bank credit. This could be explained by the fact that the more market power the banks have, the more they can charge higher lending rates and lower deposit rates to take advantage of higher annuities. These results are consistent with those of Beck et al. (2003), who find that bank concentration increases barriers to financing and decreases the likelihood of receiving bank credit. In the long run, however, the effect of concentration is not the same. The positive effect initially observed turns into a negative effect above a certain threshold (70\%), giving rise to an inverted U-shaped curve. This negative aspect could be explained by the advantage of a non-competitive market in building customer relationships. These different relationships allow the bank to facilitate monitoring, filtering and overcoming the problems of informational asymmetries they may face.

Thus, based on this information, they can offer low-interest rates to borrowers with a low risk of default, as well as to small businesses seeking financing. This is consistent with the study by Berger and Udell (1995), who admits that small firms entering into banking relationships pay lower interest rates. Similarly, Marquez (2002) has shown that borrower-specific information becomes more dispersed in competitive banking markets, leading to a less profitable selection of borrowers with higher interest rates.

Table 8. Estimation Results for Long-term parameters using the FMOLS method

Endogenous variable: COST OF CREDIT

\begin{tabular}{|c|c|c|c|c|}
\hline Variables & Coefficient & Standard deviation & T-statistics & P-value \\
\hline CR3 & $0.126 * *$ & 0.050 & 2.501 & 0.013 \\
\hline $\mathrm{CR} 3^{2}$ & $-0.9 .10^{-3} *$ & $0.3 .10^{-3}$ & -2.968 & 0.003 \\
\hline CREDIT & $-0.043 *$ & 0.025 & -1.696 & 0.092 \\
\hline GDP & -0.015 & 0.023 & -0.670 & 0.503 \\
\hline TMM & $1.235^{*}$ & 0.156 & 7.911 & 0.000 \\
\hline INF & $-0.200 *$ & 0.024 & -8.148 & 0.000 \\
\hline STP & -0.271 & 0.180 & -1.507 & 0.134 \\
\hline
\end{tabular}

Note: The asterisk * $(* *)$ indicates significance at the $1 \%(5 \%)$ levels.

Source: Author, based on data from GFDD (2018) and WDI (2018).

As regards the negative effect of the credit supply on the cost of credit, this is explained by the equilibrium that is emerging in the market for loanable funds. An increase in the supply of credit increases the availability of cash, which reduces its opportunity cost. Thus, it will reduce the cost of borrowing. In recent years, the very accommodating monetary policy of the Central Bank of West African States (BCEAO) could explain this fall in lending rates.

As for the money market rate, its increase leads to an increase in the cost of credit. The more expensive refinancing is, the more commercial banks raise the cost of the credit they provide. This shows that the interest rate can be used as an instrument of monetary policy. Indeed, in the economic literature, the interest rate is a powerful channel for monetary policy.

As for the inflation rate, the results show that it hurts the cost of credit. This result is counter-intuitive, as higher 
inflation is expected to raise banks' operating costs and increase the cost of credit. However, this negative effect could be explained by the low inflation rate in the WAEMU zone (average inflation rate is $2.26 \%$ between 1996 and 2017), which does not affect banks' real activity. Our results are in contradiction with that of Omondi (2014), who, in his study on the effects of inflation on commercial bank lending in Kenya, found that inflation had a positive and significant effect on the borrowing rate of commercial banks.

In terms of hypothesis validation, it should be recalled that this study tested two hypotheses. The first hypothesis stated that a concentrated banking market has a positive effect on the cost of credit in the WAEMU. Our results provided evidence that, indeed, when banking activity is dominated by a small number of providers, as in the WAEMU, the cost of credit increases. But above a threshold of bank concentration (70 percent), banks get to know their customers better, allowing them to offer bank credit at lower rates. Our first hypothesis that bank concentration has a positive effect on the cost of credit is therefore partially verified. Under our second assumption, the money market rate has a positive influence on the cost of credit. Indeed, when banks refinance at a high rate, they tend to implement this increase in lending rates in order to achieve high-interest margins. Thus, our second hypothesis is verified.

\section{Concluding Remarks}

The general objective of this study was to analyze the effect of the structure of the banking market on the cost of credit in the WAEMU area over the period 1996-2017. Our study focuses on WAEMU countries, with the exception of Guinea-Bissau, for which some data are missing during the study period. Two objectives were assigned. The first objective was to analyze the impact of banking market concentration on the cost of credit. The second objective was to examine the influence of the increase in the money market interest rate on the cost of credit. Methodologically, the study is based on the FMOLS estimator developed by Pedroni (1996) and Philips and Moon (1999). Our results indicate that there is an inverted "U"-shaped, or bell-shaped, the relationship between market structure and the cost of credit. It follows that bank concentration leads to high lending rates in the first instance, and to lower lending rates in the second instance, above a certain threshold (70\%). The study also notes that the money market rate positively affects the cost of credit. A rise in the cost of refinancing increases the cost of credit in the WAEMU zone. Our results indicate that, like the supply of credit, inflation negatively affects the cost of credit.

Our results may lead to some economic policy implications. The first stems from the non-linear relationship between bank concentration and the cost of credit. The existence of a threshold at which banking concentration benefits borrowers requires that monetary authorities determine the minimum level of banking competition to be encouraged. Banking activity, with its singular characteristics, requires the supervisory authorities to provide a framework for the banking sector to play its role in financing the economy of the zone. The second is that the increase in the money market rate, which most often reflects a liquidity problem on the interbank market, is not favorable to the cost of credit in the WAEMU. The BCEAO must revise its refinancing rates downwards when the economy is in decline because of the cost of refinancing conditions the supply of bank credit in the WAEMU zone. Moreover, the study shows that an increase in the supply of credit is associated with very low costs of obtaining credit. States could support monetary authorities by setting up information systems, in particular private information registers, in order to reduce information asymmetries, which are one of the causes of high lending rates.

This study found that the effect of bank concentration on the cost of credit is non-linear. The effect of banking concentration on the cost of credit may depend on the banking regulations in place or on the quality of the institutions... For this reason, further studies could be carried out to deepen the relationship between banking concentration and the cost of credit by considering the interaction of new variables with the variable of interest.

\section{References}

Acharya, V. V., Anginer, D., \& Warburton, A. J. (2016). The End of Market Discipline? Investor Expectations of Implicit Government Guarantees. Banking \& Insurance eJournal. https://doi.org/10.2139/ssrn.1961656

Adoah, I. (2015). Determinants of universal bank lending rate in Ghana (Doctoral dissertation, University of Ghana).

Anginer, A., Demirgüç-Kunt, A., \& Zhu, M. (2014). How does competition affect bank systemic risk? Journal of Financial Intermediation, 23(1), 1-26. https://doi.org/10.1016/j.jfi.2013.11.001

Asthanasoglou, P. P., Delis, M., \& Staitouras, C. (2006). Determinants of profitability in the South Eastern European Regions. Journal of Financial Decision Making, 2, 1-17.

Bagehot, W. (1873). Lombard Street, Homewood, IL: Richard D. Irwin (1962 edition). 
Bain, J. (1959). Industrial Organization. John Wiley \& Sons.

BCEAO (2019). Données statistiques économiques et financières. Retrieved from https://edenpub.bceao.int/

Beck, T., Demirguc-Kunt, A., \& Makismovic, V. (2003). Bank Competition, Financing Obstacles, and Access to Credit. The World Bank Working Paper. https://doi.org/10.1596/1813-9450-2996

Berger, A., \& Hannan, T. (1989). The price concentration relationship in banking. Review of Economics and Statistics, 71(2), 291-299. https://doi.org/10.2307/1926975

Berger, A., \& Udell, G. (1995). Relationship Lending and Lines of Credit in Small Firm Finance. The Journal of Business, 68(3), 351-81. https://doi.org/10.1086/296668

Bourke, P. (1989). Concentration and Other Determinants of Bank Profitability in Europe, North America and Australia. Journal of Banking and Finance, 13(1), 65-79. https://doi.org/10.1016/0378-4266(89)90020-4

Breitung, J., \& Das, S. (2005). Panel Unit Roots Test under Cross Sectional Dependance. Statistica Neerlandica, 59(4), 414-433. https://doi.org/10.1111/j.1467-9574.2005.00299.x

Canta, C., Nilsen, Ø. A., \& Ulsaker, S. A. (2018). Competition in local bank markets: risk taking and loan supply. The Center for Business Economics Seminar. Working papers.

Chong, T. L., Lu, L., \& Ongena, S. (2013). Does banking competition alleviate or worsen credit constraints faced by small and medium enterprises? Evidence from China. Journal of Banking and Finance, 37(9), 3412-3424. https://doi.org/10.1016/j.jbankfin.2013.05.006

Claeesens , S., \& Leaven, L. (2003). What drives bank competition? Some international evidence. Journal of Money et Credit, 36(3), 585-592. https://doi.org/10.1596/1813-9450-3113

De Bock, R., \& Alexander, D. (2012). Bank Asset Quality in Emerging Markets: Determinants and Spillovers. International Monetary Fund Working Paper WP/12/71. https://doi.org/10.5089/9781475502237.001

De Young, R., \& Noll, D. E. (1996). Foreign-owned banks in the United States: earning market share or buying it? Journal of Money Credit and Banking, 28(4), 622-636. https://doi.org/10.2307/2078074

Demsetz, H. (1973) Industry structure, market rivalry and public policy. Journal of Law and Economics, 16(1), 1-10. https://doi.org/10.1086/466752

Diagne, M. F. (2011). Bank competition, interest rates and access to finance in the WEAMU. Working Paper, 1-31. https://doi.org/10.2139/ssrn.1885106

Dietsch, M. (1992). Quel modèle de concurrence dans l'industrie bancaire? Revue Economique, 2(43), 229-260. https://doi.org/10.3406/reco.1992.409351

Engle, R. F., \& Granger, C. W. J. (1987). Cointegration and error correction representation: Estimation and testing. Econometrica, 55(2), 251-276. https://doi.org/10.2307/1913236

Ephraim, W. C., \& Montfort, M. (2004). Financial Reforms and Interest Rate Spreads in the Commercial Banking System in Malawi. IMF Staff Papers, Palgrave Macmillan, 51(1), 1-5.

Fungacova, Z., Shamshur, A., \& Weill, L. (2017). Does bank competition reduce cost of credit? Cross-country evidence from Europe. Journal of Banking and Finance, 83(10), 104-120.

https://doi.org/10.1016/j.jbankfin.2017.06.014

GFDD (2018). Global Financial Development Database. Retrieved from https://www.worldbank.org/en/publication/gfdr/data/global-financial-development-database

Hannan, T. (1991). Foundations of the S-C-P paradigm in banking. Journal of Money, Credit and banking, 23(1), 68-84. https://doi.org/10.2307/1992764

Itimu, S. M., \& Abdul, F. (2018). Determinants of average lending rates among selected commercial banks in Kenya. International Academic Journal of Economics and Finance, 3(1), 142-158.

Johansen, S. (1988). Statistical analysis of cointegration vectors. Journal of Economic Dynamics and Control, 12(2-3), 231-254. https://doi.org/10.1016/0165-1889(88)90041-3

Johansen, S. (1991), Estimation and Hypothesis Testing of Cointegration Vectors in Gaussian Vector Autoregressive Models. Econometrica, 59(6), 1551-1580. https://doi.org/10.2307/2938278

Johansen, S., \& Juselius, K. (1990). Maximum likelihood estimation and inference on cointegration-With applications to the demand for money. Oxford Bulletin of Economics and Statistics, 52(2), 169-210. https://doi.org/10.1111/j.1468-0084.1990.mp52002003.x 
Kao, C. (1999). Spurious Regression and Residual-Based Tests for Cointegration in Panel Data. Journal of Econometrics, 90(1), 1-44. https://doi.org/10.1016/S0304-4076(98)00023-2

King, R. G., \& Levine, R. (1993). Finance, entrepreneurship and growth. Journal of Monetary Economics, 32(3), 513-542. https://doi.org/10.1016/0304-3932(93)90028-E

Klein, M. (1971). A theory of the banking firm. Journal of Money, Credit and banking, 3, 205-218. https://doi.org/10.2307/1991279

Kuma, J. K. (2018). Modélisation ARDL, Test de cointégration aux bornes et Approche de Toda-Yamamoto: Éléments de théorie et pratiques sur logiciels, HAL.

Love, I., \& Martinez Peria, M. (2012). How bank competition affects firms' access to finance. World Bank Policy Research Working Paper, 6163. https://doi.org/10.1596/1813-9450-6163

Lucas, R. E. (1988). On the mechanics of Economic Development. Journal of monetary economics, 22(1), 3-42. https://doi.org/10.1016/0304-3932(88)90168-7

Marquez, R. (2002). Competition, Adverse Selection and Information Dispersion in the Banking Industry. Review of Financial Studies, 15(3), 901-926. https://doi.org/10.1093/rfs/15.3.901

Nickell, S. J. (1996). Competition and Corporate Performance. Journal of Politicla Economy. University of Chicago Press, 104(4), 724-746. https://doi.org/10.1086/262040

Omondi, O. G. (2014). Effects of Inflation on Commercial Banks' Lending: A Case of Kenya Commercial Bank Limited (Doctoral dissertation, United States International University-Africa).

Ouédraogo, S. (2012). Concentration bancaire, Profitabilité bancaire et développement financier dans l'UEMOA. Revue économique et monétaire, 12, 45-74.

Pedroni, P. (1996). Fully Modified OLS for Heterogeneous Cointegrated Panels and the Case of Purchasing Power Parity. Working Paper in Economics, Indiana University.

Pedroni, P. (1999). Critical values for cointegration tests in hetegenerous panels with multiple regressors. Oxford bulletin of economics and statistics, 61(1), 653-670. https://doi.org/10.1111/1468-0084.61.s1.14

Pedroni, P. (2001). Panel Cointegration, Asymptotic and Finite Sample Properties of Pooled Time Series Tests with an Application to the PPP Hypothesis. Working Paper in Economics, Indiana University.

Pesaran, M. H. (2007). A Simple Panel Unit Root Test in the Presence of Cross Dependance. Jouranl of Applied Econometrics, 22(2), 265-312. https://doi.org/10.1002/jae.951

Pesaran, M. H., Shin, Y., \& Smith, R. J. (2001). Bounds testing approaches to the analysis of level relationships. Journal of Applied Econometrics, 16(3), 289-326. https://doi.org/10.1002/jae.616

Petersen, M. A., \& Rajan, R. (1995). The effect of credit market competition on lending relationships. The Quaterly Journal of Economics, 110(2), 407-443. https://doi.org/10.2307/2118445

Phillips, P. C. B., \& Moon, H. R. (1999). Linear Regression Limit Theory for Nonstationary Panel Data. Econometrica, 67(5), 1057-1111. https://doi.org/10.1111/1468-0262.00070

Phillips, P. C. B. (1995). Fully modified least squares and vector autoregression. Econometrica, 63(5), 1023-1078. https://doi.org/10.2307/2171721

Phillips, P. C. B., \& Hansen, B. E. (1990). Statistical Inference in Instrumental Variables Regression with, I(1) Processes. Review of Economic Studies, 57(1), 99-125. https://doi.org/10.2307/2297545

Phillips, P. C., \& Perron, P. (1988). Testing for a unit root in time series regression. Biometrika, 75(2), 335-346. https://doi.org/10.1093/biomet/75.2.335

Robinson, J. (1952). The generalisation of the general theory. In The rate of interest and other essays. Macmillan London.

Ryan, R. M., O’Toole, C. M., \& McCann, F. (2014). Does bank market power affect sme financing constraints? Journal of Banking \& Finance, 49, 495-505. https://doi.org/10.1016/j.jbankfin.2013.12.024

Samad, A. (2008). Market Structure, Conduct and Performance: Evidence from the Bangladesh Banking Industry. Journal of Asian Economics, 19(2), 181-193. https://doi.org/10.1016/j.asieco.2007.12.007

Schaeck, K., \& Cihak, M. (2014). Competition, efficiency, and stability in banking. Financial Management, 43(1), 215-241. https://doi.org/10.1111/fima.12010 
Schumpeter, J. A. (1912). Theorie der wirtschaftlichen Entwicklung. Duncker \& Humblot, (The Theory of Economic Development, 1992, traduit par OPIE R., Cambridge, Harvard University Press, 1934).

Simpasa, A. M. (2013). Competition and market structure in the Zambian banking sector. African Development Bank Working Paper, 1-29.

Thoraneenitiyan, N. (2010). Measuring bank performance in the current evolving financial marketplace. Abac journal, 30(3), 1-14.

Turk-Ariss, R. (2010). On the implications of market power in banking: Evidence from developing countries. Journal of Banking \& Finance, 34(4), 765-775. https://doi.org/10.1016/j.jbankfin.2009.09.004

WAMU Banking Commission. (2018). Annual report of the WAMU Banking Commission-2018. Retrieved from https://www.bceao.int/sites/default/files/2019-10/Rapport_Annuel_CB_2018_BAT_Intranet.pdf

World Bank. (2018). World developpement indicators. Retrieved from http://data.worldbank.org/indicator

\section{Copyrights}

Copyright for this article is retained by the author(s), with first publication rights granted to the journal.

This is an open-access article distributed under the terms and conditions of the Creative Commons Attribution license (http://creativecommons.org/licenses/by/4.0/). 